\title{
On the presence of Dipturus nidarosiensis (Storm, 1881) in the Central Mediterranean area
}

\author{
Pierluigi Carbonara ${ }^{\text {Corresp., } 1}{ }^{\text {, Rita Cannas }}{ }^{2}$, Marilena Donnaloia ${ }^{1}$, Riccardo Melis ${ }^{2}$, Cristina Porcu ${ }^{2}$, Maria Teresa \\ Spedicato ${ }^{1}$, Walter Zupa ${ }^{1}$, Maria Cristina Follesa ${ }^{2}$ \\ ${ }^{1}$ COISPA Tecnologia \& Ricerca, Stazione Sperimentale per lo Studio delle Risorse del Mare, Bari, Italy \\ 2 Department of Life and Environmental Sciences, University of Cagliari, Cagliari, Italy \\ Corresponding Author: Pierluigi Carbonara \\ Email address: carbonara@coispa.it
}

The Norwegian skate Dipturus nidarosiensis (Storm, 1881) has only recently been recorded in the western Mediterranean Sea along the coast of southern Sardinia, off Algeria and the Alboran Sea. The present study confirmed the presence of the species in the Central Mediterranean Sea by identifying morphometric, morphological features and molecular markers. Biological sampling was conducted from 2010 to 2016 on eight specimens collected through commercial landings, offshore observer programmes and scientific surveys in Adriatic and Ionian waters at depths between 320 and $720 \mathrm{~m}$. The total lengths of the specimens (juveniles and adults) ranged from 268 to $1422 \mathrm{~mm}$, and their body weights ranged from 44.5 to $12,540.0 \mathrm{~g}$. They showed morphometric features that corresponded to those of Norwegian skates in the Northeast Atlantic and the Western Mediterranean. In previous analyses, molecular data were obtained by mitochondrial COI sequences. The haplotype network showed the occurrence of a common haplotype (Hap_1) shared by the individuals from areas in the North Atlantic, Sardinian, Algerian and Spanish Mediterranean Sea areas but not South Africa. The occurrence of individuals in different stages of life (i.e. juveniles, sub-adults and adults) and sexual development (immature and mature) suggested the presence of a species with a permanent reproductive allocation in the deep waters of the Mediterranean, which was exposed to a low level of fishing exploitation. Indeed, the deep depth distribution of the species could be the reason for the absence of information about this species in onshore or offshore fishery data collection programmes and scientific surveys. 
1 On the presence of Dipturus nidarosiensis (Storm, 1881) in

4 Pierluigi Carbonara ${ }^{1}$, Rita Cannas ${ }^{2}$, Marilena Donnaloia ${ }^{1}$, Riccardo Melis ${ }^{2}$,

5 Cristina Porcu ${ }^{2}$, Maria Teresa Spedicato ${ }^{1}$, Walter Zupa ${ }^{1}$ and Maria Cristina

6 Follesa $^{2}$

7

$8{ }^{1}$ COISPA Tecnologia \& Ricerca, Stazione Sperimentale per lo Studio delle Risorse del Mare, 9 via dei Trulli 18-20, Bari (BA), 70126, Italy.

$10 \quad 2$ Department of Life and Environmental Sciences, University of Cagliari, Cagliari, Italy, Via

11 T. Fiorelli 1, Cagliari (CA), 09126, Italy.

13 Corresponding author:

14 Pierluigi Carbonara ${ }^{1}$

15 via dei Trulli 18-20, Bari (BA), 70126, Italy

16 Email address: carbonara@coispa.it

17

Key words:

Dipturus nidarosiensis, Central Mediterranean, biodiversity skate, DNA barcoding, 20 


\section{ABSTRACT}

23 The Norwegian skate Dipturus nidarosiensis (Storm, 1881) has only recently been recorded in the 24 western Mediterranean Sea along the coast of southern Sardinia, off Algeria and the Alboran Sea.

25 The present study confirmed the presence of the species in the Central Mediterranean Sea by 26 identifying morphometric, morphological features and molecular markers. Biological sampling 27 was conducted from 2010 to 2016 on eight specimens collected through commercial landings, 28 offshore observer programmes and scientific surveys in Adriatic and Ionian waters at depths 29 between 320 and $720 \mathrm{~m}$. The total lengths of the specimens (juveniles and adults) ranged from 268 30 to $1422 \mathrm{~mm}$, and their body weights ranged from 44.5 to 12,540.0 g. They showed morphometric 31 features that corresponded to those of Norwegian skates in the Northeast Atlantic and the Western 32 Mediterranean. In previous analyses, molecular data were obtained by mitochondrial COI sequences. The haplotype network showed the occurrence of a common haplotype (Hap_1) shared by the individuals from areas in the North Atlantic, Sardinian, Algerian and Spanish Mediterranean Sea areas but not South Africa. The occurrence of individuals in different stages of life (i.e. juveniles, sub-adults and adults) and sexual development (immature and mature) suggested the presence of a species with a permanent reproductive allocation in the deep waters of the Mediterranean, which was exposed to a low level of fishing exploitation. Indeed, the deep depth distribution of the species could be the reason for the absence of information about this species in onshore or offshore fishery data collection programmes and scientific surveys.

\section{INTRODUCTION}

Species discrimination is a challenging issue mainly because it is based only on morphological diagnoses. Indeed, species classification errors are frequent because of several factors, such as phenotypic plasticity, the presence of cryptic taxa, morphological changes linked to life stage and the high level of expertise required for this kind of analysis (Herbert et al., 2003a).

The misclassification of skates is common (e.g. Serena, 2005; Frodella et al., 2016; Iglésias et al., 2010). It has been estimated that approximately 50 known species are still only partially described or completely undescribed (Coulson et al., 2011). Consequently, in recent decades, DNA-based species discrimination has been applied (Herbert et al., 2003b) in an increasing number of cases (Spouge, 2016). The use of molecular markers, specifically the cytochrome $c$ oxidase I gene (COI), 
53 has proven to be very helpful on several occasions in the identification of ray and skate species in 54 the Mediterranean, Atlantic and other waters worldwide (Ball et al., 2016; Bineesh et al., 2017; 55 Cannas et al., 2010; Cariani et al., 2017; Cerutti-Pereyra et al., 2012; Coulson et al., 2011; Frodella 56 et al., 2016; Griffiths et al., 2013; Iglésias, Toulhoat \& Sellos, 2010; Landi et al., 2014; 57 Lynghammar et al., 2014; Mabragana et al., 2011; Ordines et al., 2017; Ramirez-Amaro et al., 58 59 2017; Serra-Pereira et al., 2011; Spies et al., 2006; Vargas-Caro et al., 2016; Vella, Vella \& Schembri, 2017; Ward et al., 2008; Ward et al., 2005).

In this context, skates (Rajidae) display conservative morphological traits both among and between alive and fossil species (Valsecchi et al., 2005). Hence, for this particular taxonomic group, DNA barcoding has been used to describe new species (e.g. Last \& Séret, 2016), extirpation (e.g. Ball et al., 2016) and species' expansion range (e.g. Ordines et al., 2017). In particular, the misclassification problem is particularly crucial in the genus Dipturus (Griffiths et al., 2010; Iglésias et al., 2010). In the eastern Atlantic Ocean and in the Mediterranean Basin, such misclassification includes Dipturus batis (Linnaeus, 1758), Dipturus oxyrinchus (Linnaeus, 1758) and Dipturus nidarosiensis (Storm, 1881). There has been a high percentage of misclassification in the fishery data reported for the French coast (Iglésias et al., 2010), mostly among the following species: D. oxyrinchus, D. batis, D. nidarosiensis and Rostroraja alba (Lacepede, 1803). These findings could have led to the underestimation of the risk of a dramatic decline and collapse of the spawning stock (Griffiths et al., 2010; Iglésias et al., 2010). Hence, the risk of extinction of these species might be higher than previously calculated (Iglésias et al., 2010).

D. nidarosiensis is one of the species that is often misclassified in both the Atlantic and the Mediterranean Basin (Cannas et al., 2010; Follesa et al., 2011; Cariani et al., 2017; RamírezAmaro et al., 2017). The geographical distribution of the Norwegian skate D. nidarosiensis is known to occur along the northeast Atlantic, from Iceland, the Faroe Islands and northern Norway to Madeira and northern Mauritania (Stehmann, 1990). This species is considered endemic in the northeast Atlantic and the Bay of Biscay (Priede et al., 2010; Stehmann \& Bürkel, 1984; Rodríguez-Cabello et al., 2013). However, recently, it has been recorded in the western Mediterranean Sea, along the southern Sardinia coast (Cannas et al., 2010; Follesa et al., 2012, Cariani et al., 2017, Marongiu et al., 2017; Porcu et al., 2017), off Algeria (Cariani et al., 2017), 
84 in the Alboran Sea (Ramírez-Amaro et al., 2017) and in the southern Adriatic and Ionian Seas 85 (Cariani et al., 2017). The first catch of Norwegian skate specimens in western Mediterranean

86 87 88 90

91

92 93 94 95 96

\section{METHODS}

\section{Sampling}

113 Samples of $D$. nidarosiensis were collected on land (e.g. market sampling) along the ports of the 114 Apulia region and, from offshore observers (i.e. discard monitoring) in a fishery sampling 
115 programme (Data Collection Framework [DCF]; EU Reg. 1543/2000, 1639/2001, 1581/2004, 116 199/2008 and 1004/2017) and from fisheriesindependent scientific surveys (Mediterranean 117 International Trawl Survey - MEDITS) (AAVV, 2017) (Fig. 1). In total, eight specimens were 118 morphologically analysed and preserved in the deep freezer $\left(-20^{\circ} \mathrm{C}\right)$ at the COISPA Institute Laboratory. 119 Morphology and colour analysis as well as morphometric measurements (nearest 1 mm) (Fig. 2), weights (the nearest $1 \mathrm{~g}$ ) and meristic counts were performed following the previous descriptions of skate species (Ebert \& Stehmann, 2013; Serena, 2005). All measurements and meristic counts are shown in Figure 2 and Table 1 .

Sex and maturity were determined macroscopically, and the gonad weights were recorded to the nearest $0.1 \mathrm{~g}$. Gonadal maturity was classified using the MEDITS maturity scale (AAVV, 2017; Follesa and Carbonara, 2019). The following results are shown in Table 2: Stage 1 (virgin immature); Stage 2 (maturing); Stage 3A (mature); Stage 3B (mature/extruding active); Stage 4A (resting); Stage 4B (regenerating).

\section{Genetic analyses}

131 Eight specimens were used in the genetic analysis, four of which were previously analysed by 132 Cariani et al. (2017) (codes 1-4; Table 1) while the remaining four specimens (codes 5-8; Table 1) were analysed for the first time here.

The total genomic DNA was extracted from tissue samples using the salting-out protocol (Miller et al., 1988). These samples (skin and white muscle) were collected from the ventral side of the pectoral fin (ca. $0.5 \mathrm{~cm}^{3}$ in size). The tissue samples were preserved in $80 \%$ ethanol at $4{ }^{\circ} \mathrm{C}$.

139 The primers for the amplifications of the mitochondrial COI gene (COI-3 primer cocktail) were 140 obtained from Ivanova et al. (2007). The PCR reactions were set up in a $25-\mu 1$ reaction volume 141 containing $2.5 \mu 1$ of 10X Taq Buffer (Thermo Scientific), $2.5 \mu 1$ of $2 \mathrm{mM}$ dNTPs, $2.5 \mu 1$ of $25 \mathrm{mM}$ 142 of $\mathrm{MgCl}$,, $0.1 \mu \mathrm{l}$ of each (forward and reverse) $20 \mathrm{mM}$ primers, $0.16 \mu 1$ of Taq polymerase (Dream 143 Taq ${ }^{\circledR}$ Thermo Scientific) and $1 \mu$ l of DNA (50-100ng). The amplification was based on the

144 following cyclic parameters: $5 \mathrm{~min}$ at $94{ }^{\circ} \mathrm{C}$ for the initial denaturation, followed by 40 cycles of $14530 \mathrm{sec}$ at $94{ }^{\circ} \mathrm{C}, 40 \mathrm{sec}$ at $53{ }^{\circ} \mathrm{C}$ for the annealing of primers, $50 \mathrm{sec}$ at $72{ }^{\circ} \mathrm{C}$ for extension and 
146 then $7 \mathrm{~min}$ at $72{ }^{\circ} \mathrm{C}$ for the final extension. The PCR products were outsourced to Macrogen Europe

147 (Netherlands) for sequencing. The sequences were obtained in both directions and submitted to 148 GenBank under accession number MG699904-07. The sequences were edited and aligned in

149 MEGA v. 6 (Tamura et al., 2013) and then translated into aminoacidic sequences using the 150 vertebrate genetic code to exclude the occurrence of codon stop and nuclear pseudogenes.

151

152 The number of haplotypes, haplotype diversity [hd], average number of nucleotide differences [k] 153 and nucleotide diversity $[\pi]$ were retrieved using DnaSP v. 5.1 (Librado \& Rozas, 2009).

154 Graphically, the haplotypes were arranged in a network with PopART (http://popart.otago.ac.nz)

155 using the median-joining method (Bandelt, Forster \& Röhl, 1999).

157 The sequences obtained in this study were compared to published COI sequences for the species 158 from Mediterranean and eastern Atlantic Ocean individuals of the genus Dipturus (D. 159 nidarosiensis, D. oxyrinchus, D. batis, D. cfflossada, D. cf intermedia), which are available in 160 GenBank (https://www.ncbi.nlm.nih.gov/genbank) and BOLD (http://www.boldsystems.org/). 161 Rostroraja alba was used as the outgroup. The supplementary table (Table S1) provides the list 162 and detailed information about the sequences used in the analyses. At least three sequences per 163 species, such as $D$. intermediate and $D$. flossada, were used to a maximum of 42 sequences for $D$. 164 oxyrinchus.

The relationships among haplotypes were investigated using two approaches: the Bayesian method using MrBayes v. 3.1 (Huelsenbeck \& Ronquist, 2001; Ronquist \& Huelsenbeck, 2003) and the neighbour-joining method in MEGA using Kimura 2-parameter genetic distances (K2P; Kimura, 1980) and a bootstrap test with 1,000 replicates. In MrBayes, the analyses were performed using two parallel runs of two million generations each, using four chains, sampling every 100 generations, a burn-in of 0.25 , and saving branch lengths. The performance of the analyses was evaluated using Tracer v. 1.6 (Rambaut et al., 2014). The trees were visualised by MEGA.

\section{Ethical compliance}

175 All the Norwegian skate (Dipturus nidarosiensis) analysed in this study, which were drawn from commercial fishing activity (DCF; EU Reg. 1004/2017), did not fit the European Commission 
177 recommendations (Directive 2010/63/EU of the European Parliament and of the Council of 22

178 September 2010) or Italian National Law (Decree Law n. 26 of 4 March 2014) regarding the 179 protection of animals used for scientific experiments. Moreover, according to the welfare 180 guidelines under the Decree Law n. 26 of 4 March 2014 (Italian Ministry of Health) and the 181 protocol approved by the Committee on the Ethics of Animal Experiments of COISPA (Italian 182 Ministry of Health 15/2015-UT), the specimens brought alive onboard during the scientific survey 183 or the monitoring on the commercial fishing vessel should be killed using an overdose of 184 anaesthetic. However, all the animals sampled in this study were already dead at the time of sampling: both the specimens sampled at the landing and on board (i.e., discard monitoring and scientific survey when the specimens were brought on board).

\section{RESULTS}

189 The Norwegian skate specimens were captured around the pit of Bari and in the northwest part of 190 the Ionian Sea (Fig. 2) at depths ranging between 320 and $720 \mathrm{~m}$. All measurements, meristic 191 counts, sex and maturity are presented in Table 1. All specimens showed uniformly dark ventral 192 sides, including the ampullary pores (Fig. 3). The disc was wider (WD 64.0-74.0\% of TL) than it 193 was long (LD 52.5-59.7\% of TL), and it was covered uniformly by a darkish mucous on both sides

194 (Fig. 3). The teeth were pointed in parallel rows in the males and in molar-like sets in pavement in 195 the females (Fig. 4), with the numbers of tooth rows on the upper and lower jaws between 42-45 196 and 39-43, respectively. It appeared that the number of thorns on the tail increased with the length 197 of the specimens, as shown in Table 1. Moreover, both the dorsal and ventral sides were prickly 198 in the area of the snout (Fig. 5). Morphometric variability between the juveniles and adults was 199 detected in the relationships between the Length Tail (Ltail)/Total Length and Distance interorbital 200 (Dorb)/Total Length (Table 1). In terms of the percentage of TL, Ltail was longer in the juveniles 201 at about half of the TL, and it was one-third of the TL in the sub-adults and adults (Fig. 2). On the 202 contrary, the Dorb increased with the increasing of TL. Moreover, the juveniles did not show 203 spines on the median line of the disc or on both lateral sides of the tail, which were present in the 204 adults (Table 1). 
206 The juveniles (maturity stage 1) were caught in shallow waters at depths between 320 and $377 \mathrm{~m}$, 207 whereas the sub-adult (maturity stage 2) and adult specimens (maturity stage 3A and 3B) were 208 caught in depths ranging between 550 and $720 \mathrm{~m}$.

209 Furthermore, all samples caught during the MEDITS trawl survey were associated with a 210 biocenosis typical of compact bathyal muds. In particular, the juveniles (specimens 5, 7 and 8;

211 Table 1) caught at upper depths were found to be in association with a biocenosis characterised by 212 tall sea pen Funiculina quadrangularis facies.

213

214 Genetic analyses

215 A $633 \mathrm{bp}$ fragment of the COI gene was obtained from eight individuals from the South Adriatic 216 and Ionian seas. The combination of these data with those available for D. nidarosiensis in other 217 areas in the Mediterranean and the adjacent Atlantic Ocean provided the final alignment of 38 218 sequences and seven haplotypes (555 bp; Hd: 0.515; k: 0.586; $\pi$ : 0.00106). The haplotype network 219 (Fig. 6) showed the occurrence of a common haplotype (Hap_1) shared by 26 individuals from all 220 investigated areas except South Africa. It also showed six additional haplotypes, four of which 221 were exclusive to the Mediterranean (Hap_2-Hap_5), and two were exclusive to the Atlantic 222 (Hap_6-Hap_7).

223

224 The phylogenetic analyses (Fig. 7) further confirmed the identification of the Ionian-Adriatic 225 specimens as $D$. nidarosiensis. They were clustered in a strongly supported clade that was clearly 226 distinguishable from the other species of Dipturus found in the Mediterranean and the eastern 227 Atlantic Ocean. The sequences that were the most similar to D. nidarosiensis were those of $D$. $c f$ 228 flossada (95\% base pair similarity), and the least similar were those of $R$. alba (87.82\% base pair 229 similarity).

230

\section{DISCUSSION}

232 The results of the present study confirmed the presence of the Norwegian skate Dipturus 233 nidarosiensis in the central Mediterranean Sea by identifying morphometric and morphological 234 features and molecular markers. The morphological parameters described are in line with the data 235 collected in Sardinian waters (Cannas et al., 2010) and the Alboran Sea (Ramírez-Amaro et al., 236 2017). In particular, the relationship between the morphometric measurements and total length 
237 was similar to the data reported in the Alboran Sea (Ramírez-Amaro et al., 2017). Specifically, the 238 measurements of the juveniles from the Spanish area (Ramírez-Amaro et al., 2017) were in 239 accordance with those of the Adriatic Basin. Furthermore, the high variability in Length Tail 240 during the different stages of life seemed to be common to other Rajidae species, including $R$. 241 clavata, D. oxyrinchus and Amblyraja radiata (Mnasri et al., 2009; Capapé et al., 2015; 242 Templeman, 1987).

243

244 The genetic analysis of the mitochondrial gene COI made it possible to confirm the morphological 245 identification of the Adriatic-Ionian samples as D. nidarosiensis. In particular, in this study, the 246 molecular data revealed that the Mediterranean specimens of D. nidarosiensis (from Sardinia, 247 Algeria and the Alboran Sea) shared COI mitochondrial haplotypes with the Atlantic specimens 248 (see Table S1 for details). However, additional analyses based on more powerful markers (i.e. 249 microsatellites and SNPs) and larger numbers of individuals are needed to investigate possible 250 intraspecific differences and genetic connectivity among the different areas within the 251 Mediterranean as well as between the latter and the Atlantic populations (Griffiths et al., 2011). 252

253 The D. nidarosiensis reported in this paper were captured mainly around the Bari Pit (maximum 254 depth $=1,233 \mathrm{~m}$ ) in an area between the western Italian coast and the eastern Montenegrin and 255 Albanian coasts. This area is connected with the northern part of the Ionian Sea through the Otranto 256 Channel, and it is part of a system of currents that exchange and mix deep water from the eastern 257 part of the Mediterranean Sea and the northern part of the Adriatic Sea (Vilibic \& Orlic, 2002). 258 Although the capture locations of Norwegian skates are dispersed over 200 miles, all these areas 259 are connected by deep-water currents (Artegiani et al., 1997). In the southern Adriatic and Ionian 260 bathyal systems, there is an absence of barriers to gene flow in deep species as well as Aristeus 261 antennatus (Marra et al., 2015). In the case of $A$. antennatus, it was previously hypothesised that 262 the presence of the population could be structured into two layers: a deeper stock not affected by 263 fishing, which preserves genetic homogeneity; and an upper stock living in the fishing ground. 264 The larval dispersal, adult migration and continuous movements of individuals from deeper 265 grounds to upper areas could explain their genetic homogeneity throughout the Adriatic and Ionian 266 system (Marra et al., 2015). Similarly, the partial overlap between the Norwegian skate's habitat 
267 and fishing grounds in the Adriatic and Ionian Seas suggests that the Adriatic and Ionian $D$.

268 nidarosiensis specimens are part of the same population.

269

270 The occurrence of the Norwegian skate in the southern Adriatic Sea and northern Ionian Sea sheds

271 new light on the dispersion of this species in the Mediterranean Basin. In interviews with fishermen

272 in the southern Adriatic, it emerged that the occurrence of this species, locally called "black monk",

273 is not unusual.

274

275 However, the presence of this species in the Mediterranean was unnoticed until 2010 (Cannas et 276 al., 2010), which could be attributed to two main reasons. Firstly, it had been misclassified with 277 others species of the Dipturus genus (Cannas et al., 2010) as well as for the French coast (Iglésias 278 et al., 2010). Indeed, the presence of the Dipturus species is not recent (Griffits et al., 2011). In 279 the southern Adriatic, catches of D. oxyrinchus were reported in 1994-1995 (Relini et al., 2000; 280 Marano et al., 2003), and in the western Ionian, catches of D. batis and D. oxyrinchus were 281 recorded in 1992 and 2000-2001, respectively (Relini et al., 2000; Sion et al., 2003). In the central282 western part of the basin, D. oxyrinchus has been caught since the first surveys that were funded 283 by the DCF in mid-1980 (Relini et al., 2000, 2010). Secondly, in the southern Adriatic, the bottom 284 trawl fleet fishing grounds are concentrated on the shelf and the upper part of slope (Sabatella \& 285 Maninni, 2013). In the western Ionian, as in the other part of the basin, they are located mainly on 286 the slope to a depth of $800 \mathrm{~m}$ (Russo et al., 2017). Hence, the catches of D. nidarosiensis 287 characterised by a wider depth distribution (between 300 and 1,700 m) (Cannas et al., 2010; 288 Follesa et al., 2012; Ramírez-Amaro et al., 2017) could be unrecorded. In the studied areas, the 289 depth of the fishing activity only partially overlaps the deep distribution of the Norwegian skate. 290 In addition, in the Mediterranean sites where D. nidarosiensis specimens were found, the seabed 291 presents similar characteristics (e.g. canyons and slopes of high depths), which are favourable to 292 this species but unfavourable to the trawling activity of both commercial (Sabatella \& Maninni, 293 2013) and research vessels (AAVV, 2017).

294

295 The presence of maturing and mature males and females in early autumn (end of

296 September/beginning of October) and summer, respectively, could support previous preliminary 297 observations on the reproductive biology of the species in Sardinian waters (Follesa et al., 2012). 
298 Furthermore, the collection of empty egg cases on the sea floor as well as individuals in the 299 different life stages (embryos within egg case, juveniles, sub-adults and adults) of both sexes

300 suggests the presence of a species with a permanent reproductive allocation in the Mediterranean

301 Sea (Cannas et al., 2010; Follesa et al., 2012; Cariani et al., 2017, Porcu et al., 2017, Ramírez-

302 Amaro et al., 2017).

303

304 Based on the data recorded, despite the few specimens analysed, the Norwegian skate showed that

305 a bathymetric segregation of juveniles occurred only in the upper part of the slope, and sub-adults

306 and adults occurred at lower depths, which was previously reported in Sardinian waters (Follesa

307 et al., 2012). This deep segregation by the ontogenic phase was also observed in other species of

308 skates, including Raja clavata, R. asterias and Rhinoptera bonasus (Rouset, 1990; Ferrà et al.,

309 2016; Fisher et al., 2013). In addition, the finding of Ionian and Adriatic D. nidarosiensis

310 specimens on compact mud bottoms confirmed that the species prefers this type of sea bed, which

311 was also observed by Follesa et al. (2012) in Sardinian waters. Moreover, the present study is the

312 first to record the presence of juveniles in association with a biocenosis characterised by bathyal

313 muds with tall sea pen Funiculina quadrangularis facies.

314

315 Nevertheless, several aspects of D. nidarosiensis remain poorly investigated. For this reason, it

316 would be useful to continue the monitoring and sampling of this species in order to collect

317 additional data to clarify aspects of its biology (e.g. reproduction and growth) and ecology (e.g.

318 trophic relationship and geographical distribution).

319

320 CONCLUSION

321 The results obtained in this study confirm the presence of Dipturus nidarosiensis in the central

322 Mediterranean Sea (southern Adriatic and northwest Ionian seas) and provide information about

323 its geographical distribution, life-history and morphological traits in the Mediterranean Basin.

324 Indeed, misclassification of the Mediterranean skate species has occurred frequently (Iglésias et 325 al., 2010), resulting in the misinterpretation of several biological characteristics. The 326 morphological data were similar to those recorded in Sardinia and Alboran Sea (Cannas et al., 327 2010; Ramírez-Amaro et al., 2017). Moreover, the morphological differences between juveniles 328 and adults were highlighted in terms of morphological and meristic characteristics. The genetic 
329

330

331

332

333

334

335

336

337

338

339

340

341

342

343

344

345

346

347

348

349

350

351

352

353

354

355

356

357

358

359

360

361

362

363

364

365

analysis conducted through the mitochondrial gene COI (Spouge, 2016) made it possible to confirm the morphological identification of the Adriatic-Ionian samples as D. nidarosiensis.

\section{ACKNOWLEDGEMENTS}

The authors are grateful to the academic editor Dr. Antonina Dos Santos and three anonymous reviewers for their constructive comments and suggestions, which greatly helped to improve the manuscript.

\section{REFERENCES}

AAVV. 2017. MEDITS-Handbook. Version n.9, MEDITS Working Group : 106 pp. Available at: http://www.sibm.it/MEDITS\%202011/principaledownload.htm (accessed 26 January 2018).

Artegiani A, Bregant D, Paschini E, Pinardi N, Raicich F, Russo A. 1997. The Adriatic Sea general circulation. Part I: air-sea interaction and water mass structure. Journal of Physical Oceanography 27:1492-1514. DOI: 10.1175/1520-0485(1997)027<1492:TASGCP>2.0.CO;2

Ball RE, Serra-Pereira B, Ellis J, Genner MJ, Iglésias S, Johnson AF, Jones CS, Leslie R, Lewis J, Mariani S, Menezes G, Neat F, Noble L R, Sims D W, Griffiths AM. 2016. Resolving taxonomic uncertainty in vulnerable elasmobranchs: are the Madeira skate (Raja maderensis) and the thornback ray (Raja clavata) distinct species? Conservation Genetics 17(3):565-576. DOI: 10.1007/s10592-015-0806-1.

Bandelt H-J, Forster P, Röhl A. 1999. Median-Joining Networks for Inferring Intraspecific Phylogenies. Molecular Biology and Evolution 6(1):37-48. DOI: 10.1093/oxfordjournals.molbev.a026036

Bineesh KK, Gopalakrishnan A, Akhilesh KV, Sajeela K A, Abdussamad EM, Pillai NGK, Basheer V S, Jena J K, Ward R D. 2017. DNA barcoding reveals species composition of sharks and rays in the Indian commercial fishery. Mitochondrial DNA Part A DNA Mapping, Sequencing, and Analysis 28(4):458-472. DOI: 10.3109/19401736.2015.1137900.

Cannas R, Follesa MC, Cabiddu S, Porcu C, Salvadori S, Iglesias S P, Deiana AM, Cau A. 2010. Molecular and morphological evidence of the occurrence of the Norwegian skate Dipturus nidarosiensis (Storm, 1881) in the Mediterranean Sea. Marine Biology Research 6(4):341-350. DOI: $10.1080 / 17451000903428496$.

Capapé C, Ali M, Saad A, Alkusairy H, Reynaud C. 2015. Atypical characteristics in the longnosed skate Dipturus oxyrinchus (Linnaeus, 1758) from the coast of Syria (Eastern Mediterranean). Thalassia Salentina 37: 71-80. DOI: 10.1285/115910725v37p71

Cariani A, Messinetti S, Ferrari A, Arculeo M, Bonello J J, Bonnici L, Cannas R, Carbonara P, Cau A, Charilaou C, El Ouamari N, Fiorentino F, Follesa MC, Garofalo G, Golani D, Guarniero I, Hanner R, Hemida F, Kada O, Lo Brutto S, Mancusi C, Morey G, Schembri P J, Serena F, Sion L, Stagioni M, Tursi A, Vrgoc N, Steinke D, Tinti F. 2017. Improving the Conservation of 
366 Mediterranean Chondrichthyans: The ELASMOMED DNA Barcode Reference Library. PLoS

367 One 12(1):e0170244. DOI:10.1371/journal.pone.0170244.

368 Cerutti-Pereyra F, Meekan MG, Wei N W, O'Shea O, Bradshaw CJ, Austin CM. 2012. 369 Identification of rays through DNA barcoding: an application for ecologists. PLoS One 370 7(6):e36479. DOI:10.1371/journal.pone.0036479.

371 Coulson M, Denti W, Van Guelpen L, Miri C, Kenchington E, Bentzen P. 2011. DNA barcoding 372 of Canada's skates. Molecular Ecology Resources 11(6):968-978. DOI: 10.1111/j.1755373 0998.2011.03034.x.

374 Ebert DA, Stehmann. MFW. 2013. Sharks, batoids, and chimaeras of the North Atlantic FAO 375 Species Catalogue for Fishery Purposes. No. 7. Rome, FAO. 523 pp.

376 Ellis JR, Cruz-Martinez A, Rackham BD, Rogers SI. 2005. The distribution of chondrichthyan 377 fishes around the British Isles and implications for conservation. Journal of Northwest Atlantic 378 Fishery Science, 35:

379 Fisher RA, Call GC, Grubbs RD. 2013. Age, Growth, and Reproductive Biology of Cownose Rays 380 in Chesapeake Bay. Marine and Coastal Fisheries, 5 (1): 224-235. DOI: $381 \quad 10.1080 / 19425120.2013 .812587$

382 Follesa MC, Porcu C, Cabiddu S, Mulas A, Deiana AM, Cau A. 2011. Deep-water fish 383 assemblages in the central-western Mediterranean (south Sardinian deepwaters). Journal of 384

385 Follesa MC, Cannas R, Cabiddu S, Cau Al, Mulas A, Porcu C, Cau A. 2012. Preliminary 386 observations of the reproductive biology and diet for the Norwegian skate Dipturus nidarosiensis 387 (Rajidae) from the Central Western Mediterranean Sea. Cybium 36(3): 473-477.

388 Follesa MC, Carbonara P. 2019. Atlas of the maturity stages of Mediterranean fishery resources. 389 Studies and Reviews n. 99. Rome, FAO. 268 pp. Available at 390 www.fao.org/3/CA2740EN/ca2740en.pdf

391 Frodella N, Cannas R, Velonà A, Carbonara P, Farrell E D, Fiorentino F, Follesa M C, Garofalo 392 G, Hemida F, Mancusi C, Stagioni M, Ungaro N, Serena F, Tinti F, Cariani A. 2016. Population 393 connectivity and phylogeography of the Mediterranean endemic skate Raja polystigma and 394 evidence of its hybridization with the parapatric sibling R. montagui. Marine Ecology Progress 395 Series 554:99-113. DOI: 10.3354/meps11799

396 Griffiths AM, Sims DW, Cotterell SP, El Nagar A, Ellis JR, Lynghammar A, McHugh M, Neat 397 FC, Pade NG, Queiroz1 N, Serra-Pereira B, Rapp T, Wearmouth VJ, Genner MJ. 2010. Molecular 398 markers reveal spatially segregated cryptic species in a critically endangered fish, the common 399 skate (Dipturus batis) Proceeding of the Royal Socety B 277: 1497-1503. DOI: $400 \quad 10.1098 / \mathrm{rspb} .2009 .2111$

401 Griffiths AM, Sims DW, Johnson A, Lynghammar A, McHugh M, Bakken T, Genner MJ. 2011. 402 Levels of connectivity between longnose skate (Dipturus oxyrinchus) in the Mediterranean Sea 
403

404

405

406

407

408

409

410

411

412

413

414

415

416

417

418

419

420

421

422

423

424

425

426

427

428

429

430

431

432

433

434

435

436

437

438

439

and the north-eastern Atlantic Ocean. Conservation Genetics 12:577-582. DOI: 10.1007/s10592010-0127-3

Griffiths AM, Miller DD, Egan A, Fox J, Greenfield A, Mariani S. 2013. DNA barcoding unveils skate (Chondrichthyes: Rajidae) species diversity in 'ray' products sold across Ireland and the UK. PeerJ 1:e129. DOI:10.7717/peerj.129.

Huelsenbeck JP, Ronquist F. 2001. MRBAYES: Bayesian inference of phylogeny. Bioinformatics 17:754-755. DOI: $10.1093 /$ bioinformatics/17.8.754

Iglesias SP, Toulhoat L, Sellos DY. 2010. Taxonomic confusion and market mislabelling of threatened skates: important consequences for their conservation status. Aquatic ConservationMarine and Freshwater Ecosystems 20(3):319-333. DOI: 10.1002/aqc.1083.

Kimura M. 1980. A simple method for estimating evolutionary ratesof base substitutions through comparative studies of nucleotide sequences. Journal of Molecular Evolution 16:111-120.

Landi M, Dimech M, Arculeo M, Biondo G, Martins R, Carneiro M, Carvalho G R, Brutto S L, Costa F O. 2014. DNA Barcoding for Species Assignment: The Case of Mediterranean Marine Fishes. PLoS One 9(9):e106135. DOI:10.1371/journal.pone.0106135.

Librado P, Rozas J. 2009. DnaSP v5: a software for comprehensive analysis of DNA polymorphism data Bioinformatics, 25, (11): 1451-1452. DOI: 10.1093/bioinformatics/btp187.

Lynghammar A, Christiansen J S, Griffiths A M, Fevolden S-E, Hop H, Bakken T. 2014. DNA barcoding of the northern Northeast Atlantic skates (Chondrichthyes, Rajiformes), with remarks on the widely distributed starry ray. Zoologica Scripta 43(5):485-495. DOI: 10.1111/zsc. 12064.

Mabragana E, Martin Diaz de Astarloa J, Hanner R, Zhang J, Gonzalez Castro M. 2011. DNA Barcoding Identifies Argentine Fishes from Marine and Brackish Waters. PLoS One 6(12). DOI: 10.1371/journal.pone.0028655.

Marano CA, Manfrin Piccinetti G, Pasolini P, Tinti F, Ungaro N. 2002. Annotated checklist of the skates (Chondrichthyes, Rajidae) in the Adriatic Sea. Biologia Marina Mediterranea 10 (2): 856862.

Marongiu MF., Porcu C, Bellodi A, Cannas R, Cau A, Cuccu D, Mulas A, Follesa M C. 2017. Temporal dynamics of demersal chondrichthyan species in the central western Mediterranean Sea: The case study in Sardinia Island. Fisheries Research 193:81-94. DOI: 10.1016/j.fishres.2017.04.001

Martin Diaz De Astarloa J, Mabragana E, Hanner R, Figueroa D E. 2008. Morphological and molecular evidence for a new species of longnose skate (Rajiformes: Rajidae: Dipturus) from Argentinean waters based on DNA barcoding. Zootaxa 1921:35-46. DOI: 10.5281/zenodo. 184713 .

Marra A, Mona S, Sà RM, D’Onghia G, Maiorano P. 2015. Population Genetic History of Aristeus antennatus (Crustacea: Decapoda) in the Western and Central Mediterranean Sea. PLoS One 10(5): e0128609. DOI: 10.1371/journal.pone.0128609

PeerJ reviewing PDF | (2018:01:23717:3:0:NEW 19 Apr 2019) 
440 Mnasri N, Boumaïza M, Ben Amor MM, Capapé C. 2009. Polychromatism in the thornback ray, 441 Raja clavata (Chondrichthyes: Rajidae) off northern Tunisian coast (central Mediterranean). Pan442 American Journal of Aquatic Sciences 4(4): 572-579.

443 Ordines F, Baro J, Ramírez-Amaro S, Serena F, Sobrino I. 2017. First substantiated record of Raja 444 asterias Delaroche, 1809 (Elasmobranchii: Rajiformes: Rajidae) in the Gulf of Cádiz, North445 eastern Atlantic. Acta Ichthyologica et Piscatoria 47(1):101-106. DOI: 10.3750/aiep/02161.

446 Porcu C, Marongiu MF, Bellodi A, Cannas R, Cau A, Melis R, Mulas A, Soldovilla G, Vacca L, 447 Follesa MC. 2017. Morphological descriptions of the eggcases of skates (Rajidae) from the central448 western Mediterranean, with notes on their distribution. Helgoland Marine Research 71:10. DOI: 10.1186/s10152-017-0490-2.

450 Priede I, Godbold JA, King NJ, Collins MA, Baile Y DM, Gordon JDM. 2010. Deep-sea demersal fish species richness in the Porcupine Seabight, NE Atlantic Ocean: global and regional patterns. Marine Ecology 31: 247-260. DOI: 10.1111/j.1439-0485.2009.00330.x

453 Rambaut A, Suchard MA, Xie D, Drummond AJ. 2014. Tracer v1.6, Available at 454 http://tree.bio.ed.ac.uk/software/tracer/ (accessed 26 January 2018).

455 Ramírez-Amaro S, Ordines F, Puerto M Á, García C, Ramon C, Terrasa B, Massutí E. 2017. New 456 morphological and molecular evidence confirm the presence of the Norwegian skate Dipturus 457 nidarosiensis (Storm, 1881) in the Mediterranean Sea and extend its distribution to the western 458 basin. Mediterranean Marine Science 18(2):251-259. DOI: 10.12681/mms.1950.

459 Relini G, Biagi F, Serena F, Belluscio A, Spedicato M T, Rinelli P, Follesa MC, Piccinetti C, 460 Ungaro N, Sion L, Levi D. 2000. I selaci pescati con lo strascico nei mari italiani. Biologia Marina 461 Mediterranea 7 (1): 347-384.

462 Relini G, Mannini A, De Ranieri S, Bitetto I, Follesa MC, Gancitano V, Manfredi C, Casciaro L, 463 Sion L. 2010. Chondrichthyes caught during the Medits surveys in Italian waters. Biologia Marina 464 Mediterranea 17(1): 186-204.

465 Rodríguez-Cabello C, Pérez M, Sánchez F. 2013. New records of chondrichthyans species caught 466 in the Cantabrian Sea (southern Bay of Biscay). Journal of the Marine Biological Association of 467 the United Kingdom 93(07):1929-1939. DOI: 10.1017/s0025315413000271.

468 Ronquist, F. and J. P. Huelsenbeck. 2003. MrBayes 3: Bayesian phylogenetic inference under 469 mixed models. Bioinformatics 19:1572-1574. DOI: 10.1093/bioinformatics/btg180

470 Rousset J. 1990. Population structure of Thornback Rays Raja clavata and their movements in the 471 Bay of Douarnenez. Journal of the Marine Biological Association of the United Kingdom 70:261472268.

473 Russo T, Bitetto I, Carbonara P, Carlucci R, D’Andrea L, Facchini MT, Lembo G, Maiorano P, 474 Sion L, Spedicato MT, Tursi A, Cataudella S. 2017. A Holistic Approach to Fishery Management: 475 Evidence and Insights from a Central Mediterranean Case Study (Western Ionian Sea). Frontiers 476 in Marine Science 4:193. DOI: 10.3389/fmars.2017.00193 
477 Serena F. 2005. Field identification guide to the sharks and rays of the Mediterranean and Black 478 Sea - FAO Species Identification Guide for Fishery Purposes. Rome: FAO 97p. Available at 479 http://www.fao.org/docrep/009/y5945e/y5945e00.htm (accessed 26 January 2018).

480 Serra-Pereira B, Moura T, Griffiths A M, Serrano Gordo L, Figueiredo I. 2011. Molecular 481 barcoding of skates (Chondrichthyes: Rajidae) from the southern Northeast Atlantic. Zoologica 482 Scripta 40(1):76-84. DOI: 10.1111/j.1463-6409.2010.00461.x.

483 Sion L, Bozzano A, D'Onghia G, Capezzuto F, Panza M. 2004. Chondrichthyes species in deep 484 waters of the Mediterranean Sea. Scientia Marina 68 (Suppl 3): 153-162.

485 Sion L, D'Onghia G, Tursi A, Matarrese A. 2003. Annotated check list of the skates 486 (Chondrichthyes, Rajidae) in the North-Western Ionian Sea. Biologia Marina Mediterranea, 10 487 (2): 935-940.

488 Spies IB, Gaichas S, Stevenson DE, Orr JW, Canino MF. 2006. DNA-based identification of 489 Alaska skates (Amblyraja, Bathyraja and Raja: Rajidae) using cytochrome c oxidase subunit I (coI) 490 variation. Journal of Fish Biology 69:283-292. DOI:10.1111/j.1095-8649.2006.01286.x.

491 Spouge JL. 2016 Measurement of a Barcode's Accuracy in Identifying Species. In: Trivedi S, 492 Ansari A., Ghosh S., Rehman H. (eds) DNA Barcoding in Marine Perspectives. Springer, Cham

493 Stehmann M, Bürkel DL. 1984. Rajidae. In: Whitehead PJ, Bauchot ML, Hureau JC, Tortonese E, 494 ed. Fishes of the Northeastern Atlantic and Mediterranean. Paris: Unesco, 163-196.

495 Stehmann MFW, Ellis J, Walls R, Lynghammar A. 2015.Dipturus nidarosiensis The IUCN Red 496 List of Threatened Species 2015: e.T161729A48927468. DOI:

497 http://dx.doi.org/10.2305/IUCN.UK.2015-1.RLTS.T161729A48927468.en. (accessed 25 February 498 2018)

499 Stehmann, M. 1990. Rajidae. In Quero, JC, Hureau, JC, Karrer, C, Post, A,Saldanha, L, (eds.)

500 Check-list of the fishes of the eastern tropical Atlantic. Junta Nacional de Investigaçao

501 Cientifica e Tecnológica, Lisbon, Portugal. Vol. 1: 29-50

502 Templeman W. 1987. Length-weigth relationship, Morphometric characteristics and Thorniness 503 of Thorny skate (Raja radiata) from Northwest Atlantic. Journal of Northwest Atlantic Fishery 504 Science 7:89-98.

505 Vargas-Caro C, Bustamante C, Lamilla J, Bennett M B, Ovenden J R. 2016. The phylogenetic 506 position of the roughskin skate Dipturus trachyderma (Krefft \& Stehmann, 1975) (Rajiformes, 507 Rajidae) inferred from the mitochondrial genome. Mitochondrial DNA Part A DNA Mapping, 508 Sequencing, and Analysis 27(4):2965-2966. DOI:10.3109/19401736.2015.1060462.

509 Vella A, Vella N, Schembri S. 2017. A molecular approach towards taxonomic identification of 510 elasmobranch species from Maltese fisheries landings. Marine Genomics 36:17-23. DOI: 511 10.1016/j.margen.2017.08.008.

512 Vilibic I, Orlic M. 2002. Adriatic water masses, their rates of formation and transport through the 513 Otranto Strait. Deep Sea Research Part I: Oceanographic Research Papers 16: 171-178. DOI: 514 10.1016/S0967-0637(02)00028-6 
515 Ward RD, Holmes BH, White WT, Last PR. 2008. DNA barcoding Australasian chondrichthyans: 516 results and potential uses in conservation. Marine and Freshwater Research 59(1):57-71. DOI: 517 10.1071/MF07148.

518 Ward RD, Zemlak TS, Innes BH, Last PR, Hebert PD. 2005. DNA barcoding Australia's fish 519 species. Philosophical transactions of the Royal Society of London Series B, Biological sciences 520 360(1462):1847-57. DOI:10.1098/rstb.2005.1716.

521 Williams T, Helle K, Aschan M. 2008. The distribution of chondrichthyans along the northern 522 coast of Norway. ICES Journal of Marine Science 65: 1161-1174. DOI: 10.1093/icesjms/fsn103

523 Zupa W, Donnaloia M, Gaudio P, Intini S, Carbonara P. 2010. Occurence of Leucoraja fullonica 524 (Linnaeus, 1758) in the south Adriatic Sea. Biologia Marina Mediterranea 17 (1): 260-261.

525

526 
Figure 1

The geographical locations of the $D$. nidarosiensis catches

Spatial distribution of Norwegian skate Dipturus nidarosiensis caught during 2010-2016. The numbers correspond to the specimen codes reported in Table 1.

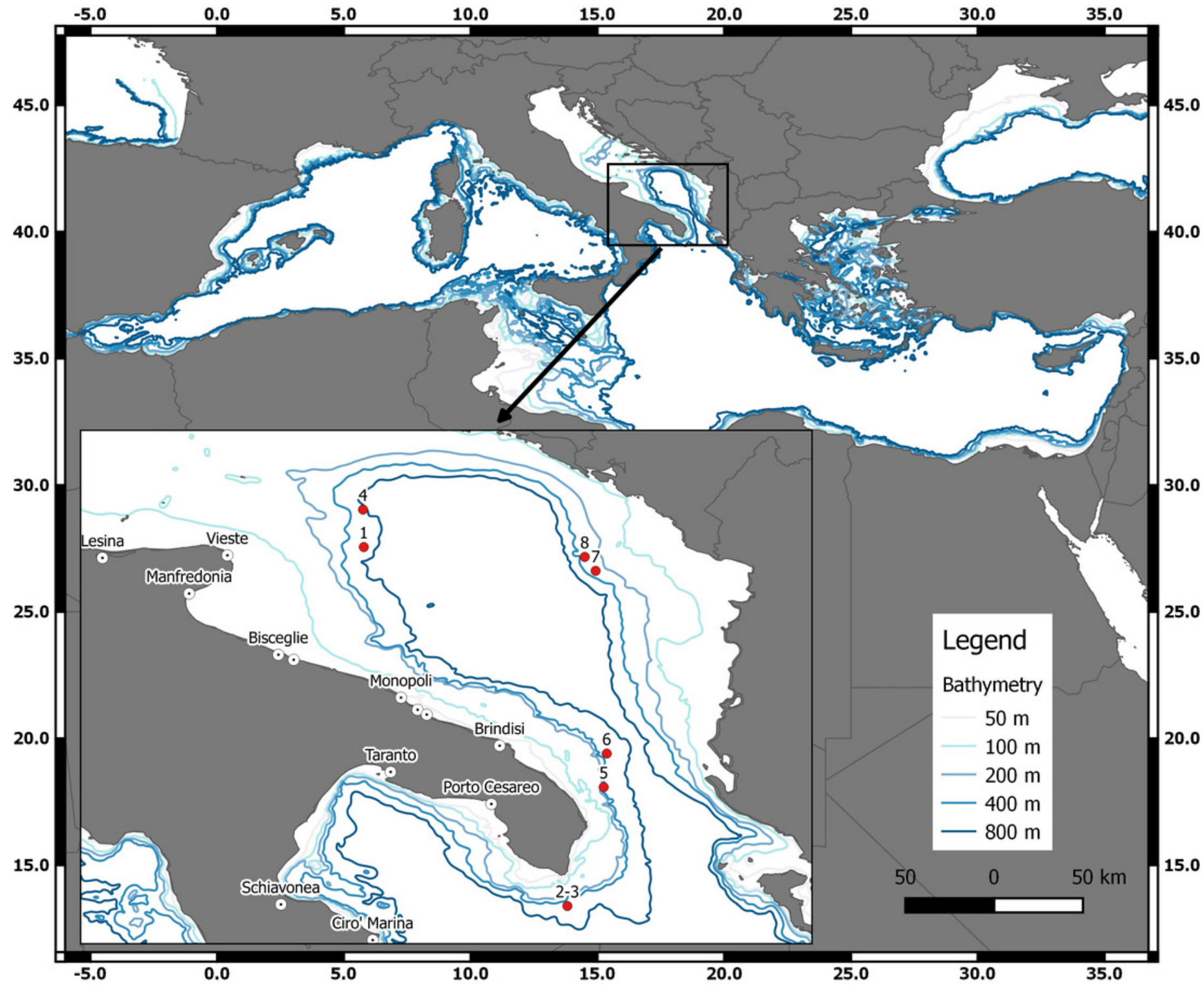




\section{Figure 2}

The morphometric measurements recorded for $D$. nidarosiensis specimens

Schematic representation of the morphometric measurements recorded for Dipturus

nidarosiensis specimens caught in the central Mediterranean Sea. Dorsal view at left (A) and ventral view at right (B). Total Length (TL); Disc Length (DL); Pre $1^{\circ}$ dorsal fin Length (L1P);

Pre $2^{\circ}$ dorsal fin Length (L2P); Preorbital or snout length (Sporb); Preoral Length (SP); Interorbital Length (Dorb); Internostril Length (Dnos), Disc Width (DW); Tail Length (Ltail).

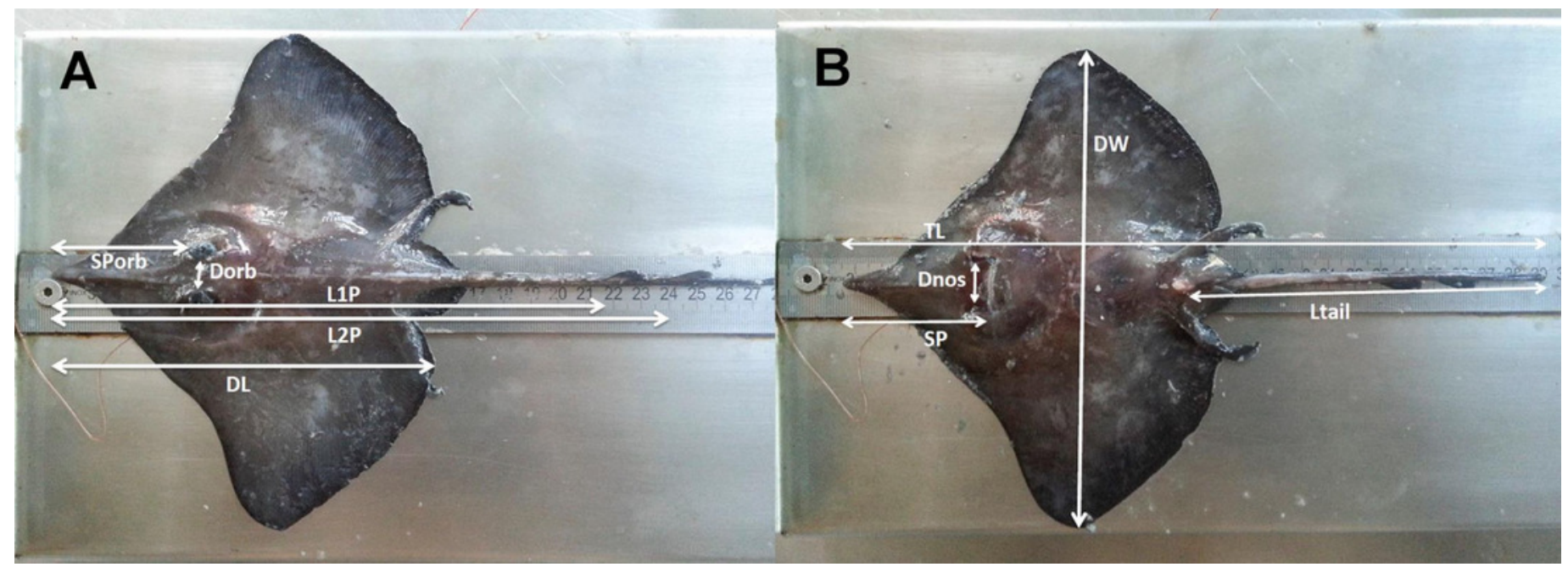




\section{Figure 3}

Juvenile and adult specimens (dorsal-ventral view) of $D$. nidarosiensis

Juvenile ( $A$ : dorsal view; B: ventral view) and adult female (C: dorsal view; D: ventral view) of Dipturus nidarosiensis. Photo: Pierluigi Carbonara. 







\section{Figure 4}

The mouth of female and male $D$. nidarosiensis specimens

Detail of the mouth of $(A)$ female with molar-like teeth and $(B)$ male with pointed teeth. Photo: Pierluigi Carbonara.
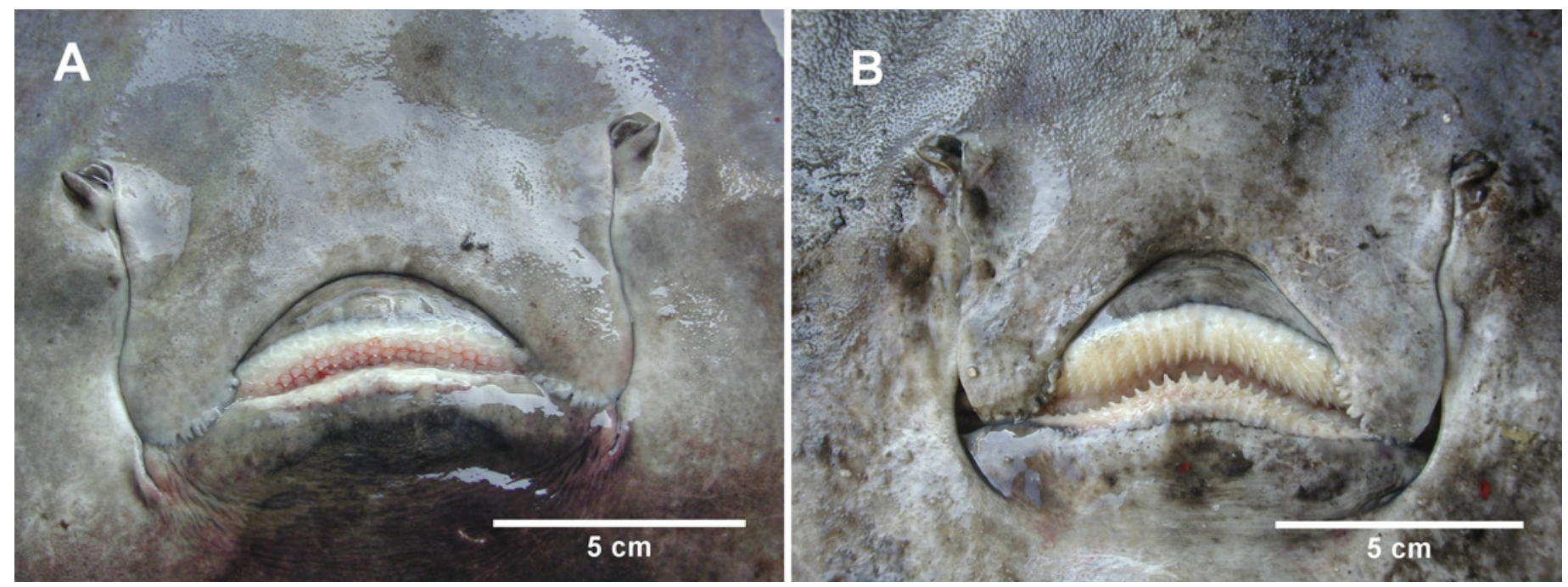


\section{Figure 5}

The snout of $D$. nidarosiensis

Detail of the snout (A) dorsal and (B) ventral side. Photo: Pierluigi Carbonara.

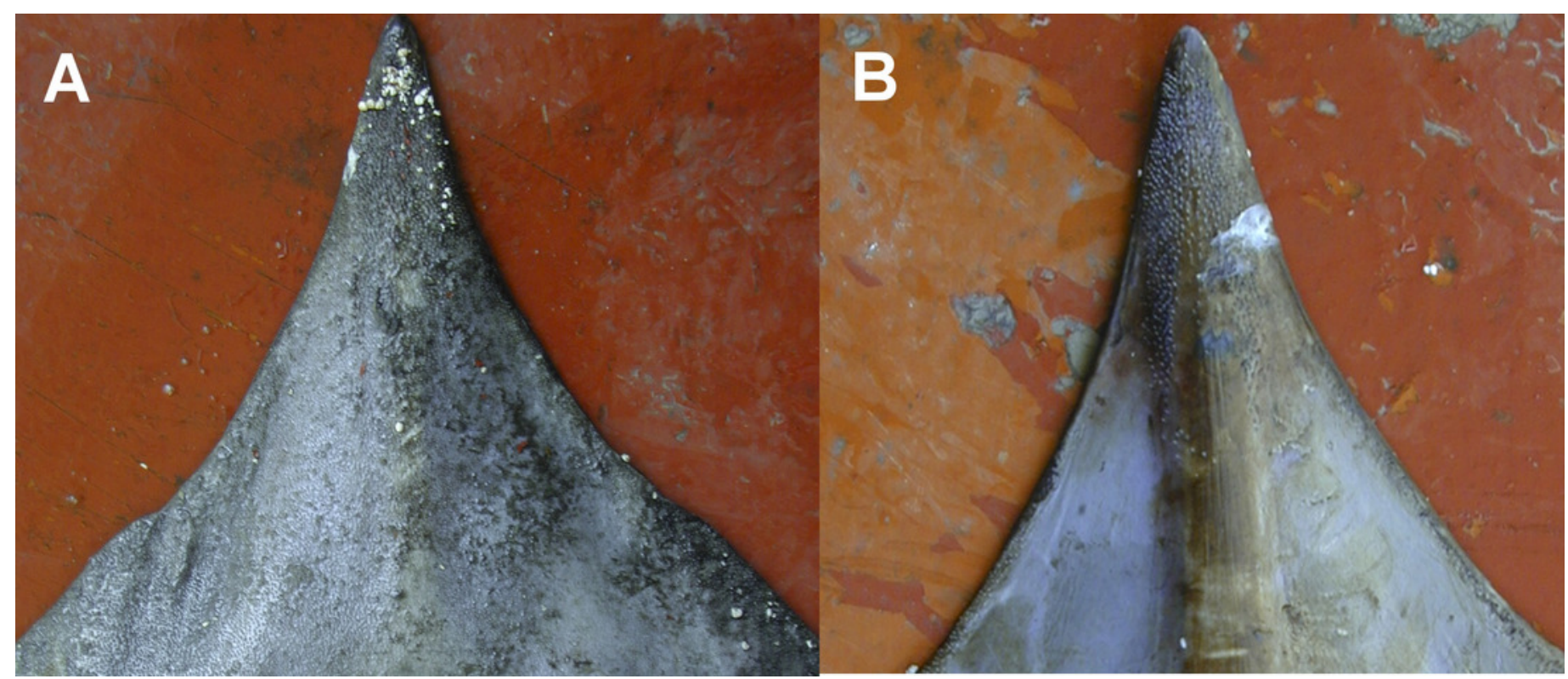




\section{Figure 6}

Median-Joining network of the COI haplotypes

Median-Joining network of the $\mathrm{COI}$ haplotypes. Each circle represents a haplotype, and the area of the circle is proportional to the haplotype frequency. All mutational steps are equal to 1 and are represented with a vertical line. Colours correspond to different areas of origin of the sequence $(\mathrm{SAF}=$ South Africa; $\mathrm{ATL}$ : Northeast Atlantic; $\mathrm{ALB}=$ Alboran Sea; $\mathrm{ALG}=$ Algeria; $S A R=$ Sardinia; $I A D=$ Ionian + Adriatic seas). Haplotype code correspondence is shown in Table S1. 


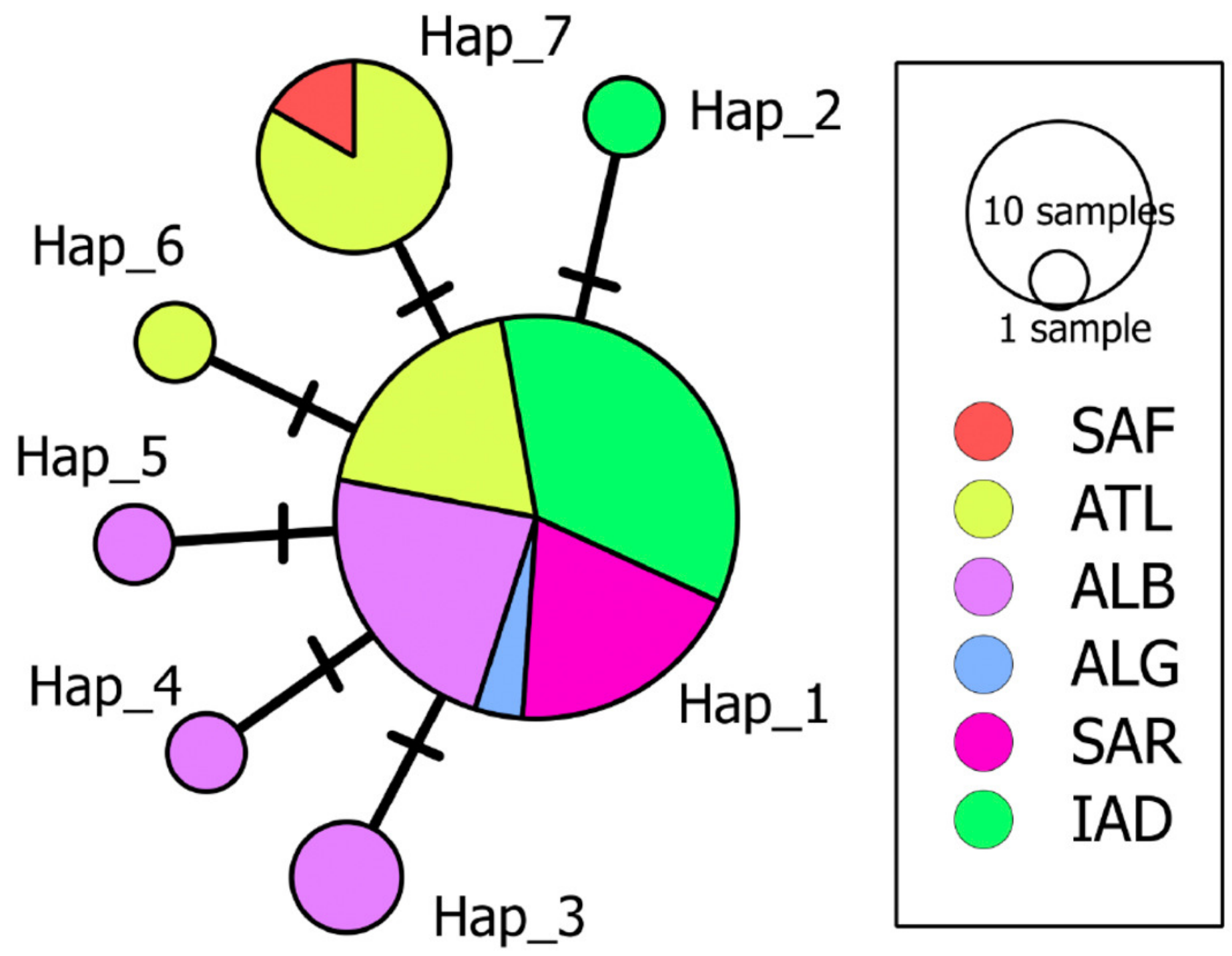


Figure 7

Phylogenetic tree

Phylogenetic tree based on mitochondrial COI sequences. Bootstrap/posterior probability values $>70$ are shown next to the nodes for the Neighbour Joining and Bayesian methods, respectively. In red the clade were the Ionian-Adriatic sequences clustered.

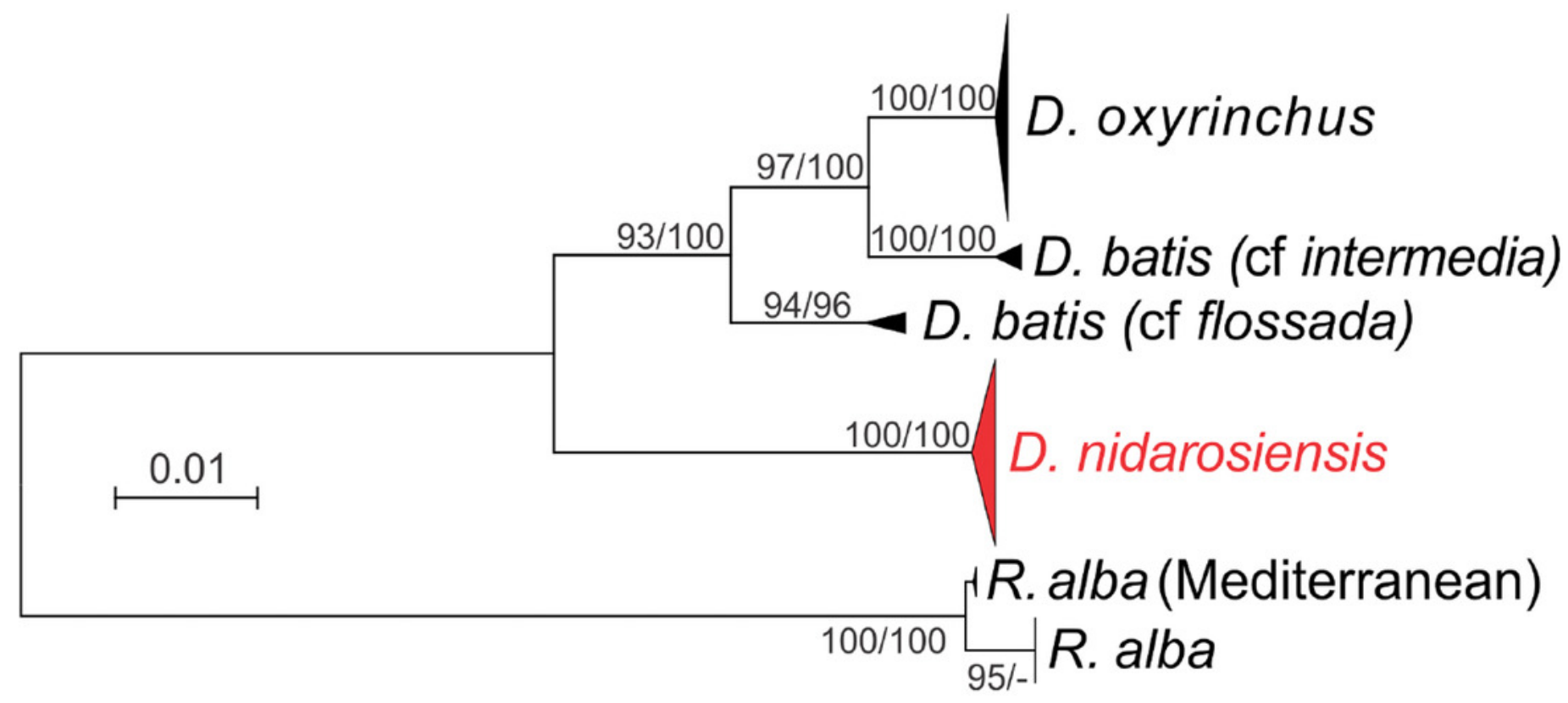




\section{Table $\mathbf{1}$ (on next page)}

The morphometrics, meristics, sexes, maturity, depth, dates of capture and origins data are reported

Summary of data collected from commercial landings and scientific surveys, NA: not available. 


\begin{tabular}{|c|c|c|c|c|c|c|c|c|}
\hline Code specimens & 1 & 2 & 3 & 4 & 5 & 6 & 7 & 8 \\
\hline Date & $29 / 09 / 2010$ & $\begin{array}{c}31 / 07 / 201 \\
1\end{array}$ & $\begin{array}{c}31 / 07 / 201 \\
1\end{array}$ & 06/10/2011 & $\begin{array}{c}13 / 08 / 201 \\
4\end{array}$ & $13 / 08 / 2014$ & $\begin{array}{c}02 / 08 / 201 \\
5\end{array}$ & $\begin{array}{c}01 / 08 / 201 \\
6\end{array}$ \\
\hline Source & $\begin{array}{l}\text { Landing } \\
\text { (Market) }\end{array}$ & $\begin{array}{c}\text { Landing } \\
\text { (Discards) } \\
\end{array}$ & $\begin{array}{l}\text { Landing } \\
\text { (Discards) }\end{array}$ & $\begin{array}{l}\text { Landing } \\
\text { (Market) }\end{array}$ & MEDITS & MEDITS & MEDITS & MEDITS \\
\hline Depth (m) & 610 & 600 & 600 & 720 & 377 & 550 & 373 & 320 \\
\hline \multicolumn{9}{|c|}{ Morphometric measurements (mm) - Percentage of total length (\%) } \\
\hline Total Length (TL) & 1235 & 705 & 912 & 1194 & 269 & 1422 & 356 & 305 \\
\hline Width Disc (WD) & $855-69.2$ & $511-72.5$ & $653-71.6$ & $884-74.0$ & $186-69.1$ & $1003-70.5$ & $228-64.0$ & $215-70.5$ \\
\hline Length Disc (LD) & $720-58.3$ & $415-58.9$ & $524-57.5$ & $713-59.7$ & $146-54.3$ & $842-59.2$ & $187-52.5$ & $172-56.4$ \\
\hline $\begin{array}{l}\text { Length } 1^{\circ} \text { dorsal fin } \\
\text { (L1P) }\end{array}$ & $1020-82.6$ & $560-79.3$ & $723-79.3$ & $977-81.8$ & $206-76.6$ & $1162-81.7$ & $252-70.8$ & $237-77.7$ \\
\hline $\begin{array}{l}\text { Length } 2^{\circ} \text { dorsal fin } \\
\text { (L2P) }\end{array}$ & $1087-88$ & $622-88.2$ & 80287.9 & $1049-87.9$ & $229-85.1$ & $1259-88.5$ & $282-79.2$ & $266-87.2$ \\
\hline $\begin{array}{l}\text { Distance } \\
\text { interorbital (Dorb) }\end{array}$ & $63-5.1$ & $34-4.8$ & $46-5$ & $59-4.9$ & $12-4.5$ & $75-5.3$ & $15-4.2$ & $14-4.6$ \\
\hline $\begin{array}{l}\text { Distance } \\
\text { internostril (Dnos) }\end{array}$ & $99-8$ & $55-7.8$ & $74-8.1$ & $98-8.2$ & $19-7.1$ & $114-8$ & $25-7$ & $20-6.6$ \\
\hline $\begin{array}{l}\text { Snout preorbital } \\
\text { Sporb (Sporb) }\end{array}$ & $246-19.9$ & $141-20$ & $181-19.8$ & $242-20.3$ & $51-18.9$ & $286-20.1$ & $67-18.8$ & $63-20.7$ \\
\hline Snout preoral (SP) & $228-18.5$ & $133-18.9$ & $173-19$ & $215-18$ & $56-20.8$ & $314-22.1$ & $69-19.4$ & $68-22.3$ \\
\hline Length Tail (Ltail) & $416-33.7$ & $240-34$ & $309-33.9$ & $412-34.5$ & $136-50.6$ & $568-39.9$ & $160-44.9$ & $157-51.5$ \\
\hline \multicolumn{9}{|c|}{ Meristic counts $\left(\mathrm{N}^{\circ}\right)$} \\
\hline $\begin{array}{l}\text { Thorns on median } \\
\text { row disc }\end{array}$ & 20 & 12 & 12 & 15 & 0 & 19 & 0 & 0 \\
\hline $\begin{array}{l}\text { Median thorns on } \\
\text { tail }\end{array}$ & 32 & 18 & 23 & 33 & 9 & 35 & 10 & 11 \\
\hline Lateral torn on tail & 35 & 30 & 34 & 37 & 0 & 33 & 0 & 0 \\
\hline Rows of teeth upper & 44 & 45 & 43 & 44 & 44 & 45 & 42 & 42 \\
\hline
\end{tabular}




\begin{tabular}{l|l|l|l|l|l|l|l|} 
jaw & & & & & & \\
\hline $\begin{array}{l}\text { Rows of teeth lower } \\
\text { jaw }\end{array}$ & 42 & 43 & 41 & 42 & 42 & 43 & 39 \\
\hline Gill slits & 5 & 5 & 5 & 5 & 5 & 5 & 5 \\
\hline
\end{tabular}

Weight (g)

\begin{tabular}{l|c|c|c|c|c|c|c|c}
\hline Total Weight & 10043 & 1138 & 2596 & 9200 & 45 & 12540 & 105 & 75 \\
\hline Gonad weight & 60 & 1.9 & 6.9 & 400 & NA & 58 & NA & NA \\
\hline Liver weight & 560 & 44.4 & 133.6 & 495.7 & 1.4 & 62.7 & 1.8 & 1.6 \\
\hline Gutted weight & 8140 & 1023.1 & 2250.4 & 8580 & 39.6 & 11090 & 71.8 & 62.2 \\
\hline
\end{tabular}

Sex and Maturity

\begin{tabular}{l|c|c|c|c|c|c|c|c}
\hline Sex & Male & Male & Male & Female & Female & Female & Male & Female \\
\hline Maturity & 3B & 3A & 3A & 3A & 1 & 2 & 1 & 1
\end{tabular}




\section{Table 2 (on next page)}

The description of the maturity scale, used in this study

Maturity scale for the Elasmobranch oviparous species (AAVV, 2017; Follesa and Carbonara, 2019) 


\begin{tabular}{|c|c|c|c|}
\hline \multirow{2}{*}{ STAGE } & \multirow{2}{*}{ MATURATION STATE } & \multicolumn{2}{|c|}{ REPRODUCTIVE APPARATUS ASPECT } \\
\hline & & FEMALES & MALES \\
\hline 1 & IMMATURE/VIRGIN & $\begin{array}{l}\text { Ovaries barely discernible with small } \\
\text { isodiametric follicles. Distal part of oviducts } \\
\text { thick-walled and whitish. Oviducal glands not } \\
\text { clearly visible. }\end{array}$ & $\begin{array}{l}\text { Small and flaccid claspers not reaching the } \\
\text { posterior edge of the pelvic fins. Spermducts not } \\
\text { differentiated. Small and narrow testes.. }\end{array}$ \\
\hline 2 & MATURING & $\begin{array}{l}\text { Whitish and/or few yellow maturing follicles } \\
\text { visible in the ovary. Distal part of oviducts } \\
\text { (uteri) well developed but empty. Developing } \\
\text { oviducal glands. }\end{array}$ & $\begin{array}{l}\text { Clasper extending past the posterior edge of the } \\
\text { pelvic fins. Spermducts well developed, and } \\
\text { starting to meander. }\end{array}$ \\
\hline $\mathbf{3 A}$ & MATURE & $\begin{array}{l}\text { Ovaries with yellow follicles (large yolk } \\
\text { follicles). Enlarged oviducal glands and } \\
\text { distended oviducts. }\end{array}$ & $\begin{array}{l}\text { Hard and ossified claspers extendings well } \\
\text { beyond the posterior edge of the pelvic fin. with } \\
\text { internal structure is generally. Testes greatly } \\
\text { enlarged. Spermducts meandering over almost } \\
\text { their entire length. }\end{array}$ \\
\hline 3B & $\begin{array}{l}\text { MATURE/EXTRUDING/ } \\
\text { ACTIVE }\end{array}$ & $\begin{array}{l}\text { Ovaries walls transparent. White or yellow } \\
\text { follicles. Large oviducal glands. Egg-cases } \\
\text { more or less formed in the oviducts (Extruding } \\
\text { Stage). }\end{array}$ & $\begin{array}{l}\text { Clasper longer than tips of posterior pelvic fin } \\
\text { lobes, skeleton hardened with axial cartilages } \\
\text { hardened and pointed. Spermducts largely. Sperm } \\
\text { flowing on pressure from cloaca (Active Stage). }\end{array}$ \\
\hline $\mathbf{4 A}$ & RESTING & $\begin{array}{l}\text { Ovaries walls transparent. White or yellow } \\
\text { follicles. Enlarged oviducts, collapsed and } \\
\text { empty. Reduced oviducal glands diameter. }\end{array}$ & $\begin{array}{l}\text { Clasper longer than tips of posterior pelvic fin } \\
\text { lobes, skeleton hardened withaxial cartilages still } \\
\text { hardened. Spermducts empty and flaccid. }\end{array}$ \\
\hline $4 B$ & REGENERATING & $\begin{array}{l}\text { Ovaries full of small follicles similar to stage } 2 \text {, } \\
\text { enlarged oviducal glands and uteri }\end{array}$ & $\begin{array}{l}\text { Clasper longer than tips of posterior pelvic fin } \\
\text { lobes, skeleton hardened withaxial cartilages still } \\
\text { hardened. Spermducts empty and flaccid. }\end{array}$ \\
\hline
\end{tabular}

